\title{
EDUCATIONAL DUALISM IN THE MUSLIM WORLD AND THE WAY FORWARD: A COMPARATIVE STUDY OF EDUCATIONAL THOUGHT OF MAWLANA MADOODI AND BADIUZZAMAN SAID NURSI
}

\author{
Javaid A. Sheikh
}

Political Science. Department of Higher Education Government of Jammu and Kashmir, India.

*Corresponding Author Email ID: sunatjavaidps@gmail.com

\section{A B S T R A C T}

There is no denying of the fact that Islam lays a great thrust on education but the duality in the education system has created a huge gulf between the secular and the sacred. Generally speaking, religious educational institutions have been cut off from scientific knowledge and hence from the world altogether, and the secular educational institutions are cut off from the Wahi (the Divine guidance), hence cut off from the other world. Under the prevailing setup, both systems are inadequate to produce the desired man-the Khalifa. Therefore, integration of both streams of knowledge is accepted as the only solution not only for the progress and development of the Muslim world but also for curbing and eliminating fundamentalism and religious intolerance. The paper aims to find solutions to this dualism in the views of Syed Maududi and Said Nursi. Both Maududi and Nursi have advocated an integrated system of education where the worldly and the other-worldly knowledge can be clubbed together. However, it is to be admitted that Maududi's educational approach is more ideology centric while as Said Nursi's approach is faith based. The study aims to understand comparatively and critically the educational thoughts of Sayyed Maududi and Said Nursi.

Keywords: Madrasa education, educational philosophy, Risale-i-Nur, Medresetu'z-Zehra, Integration of education, Maududi and education, Said Nursi and education, educational dualism, Khalifa

\section{INTRODUCTION}

Sayeed Maududi defines knowledge as the sum total of information acquired through Sama (listening), Basar (seeing) and Fuaad. For Maududi Sama means acquiring established forms of knowledge, both ancient and modern, Basar implies gaining knowledge through personal observation, and Fuaad (perceiving) means arriving at conclusions based on that acquired knowledge (Maududi, 2103; Maududi, 2018). Maududi states that 'a nation assumes leadership when it devotes itself unsparingly to the pursuit of knowledge handed down to it from the past as well as present when it steadily engages itself to add new dimensions to its knowledge when it arrives at its own conclusions by reordering the knowledge of impurities in the light of its own findings and deductions. It improves upon borrowed knowledge as new facts emerge. Thus equipped, it strives to restructure the social order to the best of its ability. So long as a nation is characterized by these qualities it enjoys superiority over others (Maududi, 2009). Maududi looked upon these faculties as the source of knowledge. For Maududi, the purpose of education is to shape the personality of the younger generations by developing their potential so as to make them useful members of society (Maududi, 2009).

Knowledge can be defined as the outcome of the encounter between the human mind and its environment. If so, then the pedagogy for encountering the environment needs to be defined and drafted. Said Nursi provides us with that pedagogy. For Said Nursi, the epistemological framework to encounter, understand and interpret the created Quran (the cosmos) is the belief in God. Nursi believed that there are two holy books man must read- the revealed Book (the Quran) and the created book (the Cosmos) (Nursi, 2015). To him, the source of knowledge is 'I' (man's ego), which 
Nursi believe, was a Trust $^{1}$ given to Almighty to the humans. This ego is the key to unlock the hidden treasures of the cosmos to reach to the creator (Nursi, 2015). He believes, as Markham (2011) as put it, that unless humans were provided skills of comprehension, speech, seeing, hearing, and all capacities for understanding, it would not be possible for them to grasp Divine attributes and the ways they operate in the cosmos (Markham, 2011). Nursi places a huge emphasis on reading the created Book for knowing the Gaib ul Gayoob (unseen of the unseen). For him, the first revealed verse Iqra (read) does not mean only to read the words of God from the revealed Book but also the words of God as made manifest in the created realm. Nursi believed that in the command to 'read' there was also the command to interpret. However, the created Book can be read from two different and opposed hermeneutical positions, that is mania-i-ismi (self-referential) and mania-i-harfi (Other-indicative). Simply stated, either one interprets the cosmic verses as indicating none other than their own existence or interpreting them as signs pointing to the Creator (Turner, 2009). Nursi places huge stress on knowing the Creator through His creation. So any attempt to understand the created world must be an attempt to reach to the Creator. His Risale-i-Nur contains many passages that instruct to employ the 'Other-indicative' frame to understand the Creator. 2 This 'Other-indicative' frame, believes Markham, guides one to pass from cause to the source of the cause (Markham and Birinci, 2011).

This faith-based approach of knowledge is a peculiar characteristic of Nursi's educational thought. Maududi also lays a great stress in faith-based methodology for teaching both natural as well as social sciences. For he believed that if sciences are taught without any reference to Allah then the world becomes a godless one (Maududi, 2013). Maududi puts huge emphasis on accepting the sovereignty of Allah by knowing and understanding the complex phenomenon of the universe while as for Nuri understanding of the Created Book must be a way to reach to the creator, to accept his existence. However, both Nursi and Maududi came to the conclusion that centuries old monarchical rule, colonialism and the autocratic rule of their own people have brought about moral and spiritual degeneration of Muslims throughout the world. To retrieve them from this degeneration, both felt the necessity of reforming the education system. Nursi educational reforms were faith based and aimed to strengthen the belief in the tenets of Islam as he believed that the contemporary problems in Muslim world had roots in the weakness of faith and throughout his life, he dedicated his writings and endeavors to this cause. On the other hand, Maududi's educational reforms were fascinated with his notion of Islamism where he believed, like Plato ${ }^{3}$ that education should serve the ideal state (Maududi's Islamic state).

\section{FINDING THE CONTEXT OF THEIR THOUGHT}

Said Nursi and Sayyid Maududi were contemporaries and experienced almost the same socio-political events albeit in two different geographies. Maududi was born on $25^{\text {th }}$ of September 1903 in Hyderabad and died on $22^{\text {nd }}$ of September 1979 (Nasr, 1994). There is no denying of the fact that his thought (political, social and educational) was shaped by different historical events (domestic as well as foreign) in the interwar period. These events deeply influenced the mind of Maududi and provided him the required context for developing his revolutionary religious thought. Same can be said about Said Nuri, who was born in $1878^{4}$ and died on $23^{\text {rd }}$ March 1960. Both Maududi and Nursi lived in one of the most significant periods of human history. They saw the two world wars, the collapse of the Ottoman Empire and the emergence of a secular Republic of Turkey; they experienced colonization and decolonization of Muslim lands, they saw rising and dying of different ideologies; they saw the onslaught of modernization, westernization and secularization in Muslims lands; but they perceived these experiences differently and came to altogether different conclusions. Nursi perceived the decline of the Muslim world in weakening of the belief and concentrates all his energies in reviving the belief of the people. Nursi, while explaining the root cause of the decline of the Muslim world (especially of the collapse of the Ottoman Empire), stated that the missing point was not political and economic reforms but the deviation in faith or faithlessness. To him, it was not the state that collapsed rather it was people that collapsed. So rebuilding and reconstruction must come from below. The reconstruction of people's lives became the base and the goal for Noor Movement.

Maududi on the other hand, looked on the decline of the Muslim world in political terms and came to the conclusion that establishment of an Islamic state was the only way forward. But ideology alone was not enough, 
for establishing Islamic state an Islamic party that would become a vanguard for Islamic revolution, was inevitable (Nasr, 1994). Maududi states that in 1926, when he wrote Al-Jihad fill Islam, the idea of Islamic revivalism took roots in his mind with a firm belief that establishment of an Islamic state was the only means to regain the lost glory and power of the Muslim world (Maududi, 2013). Maududi states that once a civilization loses political power its ideology and its knowledge become powerless (Maududi, 2013). This political aspect has overshadowed all other aspects in Maududi's thought. His ideas about education need to be understood in this context.

Said Nursi did try in the early years (Old Said) to revive Islam and society by means of politics but once he realized that the state in Attaturk's new Turkey was going to be a secular state, he abandoned political and social activism and decided to revive the faith of the individuals, hence choose a bottom-top approach for socio-political change. The years that saw the transition of Turkey from Empire to Republic, also saw the transition of Said Nursi from 'Old Said' to 'New Said' (Nursi, 2010). Colin Turner (2009) writes that Nursi's stay in Ankara ${ }^{5}$ convinced him that in the then situation any attempt to ameliorate the situation politically would be fruitless. So, he emphasized on belief and stated that man's true happiness and progress could be achieved through the adoption of new forms of education and theology (Turner, 2009: 33). Nursi concluded that serving Islam by means of politics is of little significance when compared it with serving it through belief and fostered all his energies to foster a culture of belief upon which modern and successful society can be based (Turner, 2009: 33).

\section{DUALISM IN MUSLIM EDUCATION SYSTEM AND THE WAY FORWARD: MAUDUDI'S PERSPECTIVE}

Said Nursi and Sayyed Maududi did not receive conventional education of their times. They did not fit in the education systems of their times, hence were disappointed with the entire system of education. It was the time when, almost in the entire Muslim world, the education had got divided into religious sciences and the modern sciences. The religious sciences were taught in Madrasas and the modern sciences in secular institutions called Maktabs. Both, Nursi as well as Maududi were troubled by this dualism and concluded that none of the systems serve the purpose. The
Madrasas were cut off from the modern sciences, hence were unable to solve the problems of day today life. On the other hand, the secular institutions were cut off from Wahi hence were taking society towards disbelief, corruption and various other evils.

Maududi believed that with every passing day, the Medrasas became misfits, hence were fast losing their relevance. To him the products of these institutions were intellectually ossified hence were unable to serve no other purpose in the society than that of running a mosque or establishing a similar kind of a madrasa or creating religious factions (Maududi, 2015; Maududi, 2012). Maududi states that the Madrasa education became redundant not because of ir-religiosity, or growing modernization, Westernization or secularization, rather, for it being outdated and not being in compatibility with the existing political order. $\mathrm{He}$ is not ready to accept the traditional education system as religious education system; rather to him, this system was adopted to meet the requirements of civil services in the pre-colonial era (Maududi, 2015; Maududi, 2012). To him change in political structure left this system obsolete and irrelevant. He criticized the traditional education for not being revolutionary (Maududi, 2015). Maududi cautions that 'when a community is content with its achievements, when its thirst for knowledge is slaked, when its academic pursuits are confined to what has been handed down from the past, and when it lapses into the misconception that what has been achieved by its forbears is sufficient and calls for no further exploration. He further states that when a community sinks into such a state of inertia it is supplanted by others. This reverses the course of history: the leader becomes a follower, and a follower, a leader (Maududi, 2013).

Similarly, he criticized the modern system of education for being alien, secular and atheistic, devoid of Islamic morality (Maududi, 2013). He even went to the extent of calling these institutions 'slaughterhouses' where students were slaughtered on a regular basis (Maududi, 2013). Secular systems, he believed, define the aim and scope of life, the principles of morality, the culture and conduct of individuals as well as collective life from purely atheistic point of view hence are antithetical to godly code of conduct and morality (Maududi, 2013). He then states categorically that under a godless leadership a godly ideology cannot survive. It is therefore, obligatory for the Muslims to replace this faithless 
leadership through a revolution but he did not find the existing system of education capable of bringing any revolution nor finds it capable of equipping the young generation with the spirit of revolution (Maududi, 2013). For him both the systems of education are impotent to produce the desired men-the Khalifah. Maududi believed that education alone grants mankind the vicegerency of Allah on earth. He firmly believed that if Muslims have to get back their lost glory reformation in the system of education was must. He proposed, what can be called as the 'Islamization of Knowledge' as he believed that amalgamation of modern sciences with religious sciences cannot bring the desired revolution in the leadership; in contrary, he believes that mixing the two contradictory systems might bring harm for the entire society. In his words:

Those inspired by traditional learning will become religious divines; those impressed by modern learning will be westernized; the rest of them, assailed by conflicting ideologies, will grope in darkness. Probably very few people under this system will be so equipped as to strike a balance between the two and direct the course of their lives I the right direction (Maududi, 2013).

He believed that blending of religious and secular education was a response to the crisis developed by implementation of the secular system of education which barred the avenues of employment to the students passing out from the traditional Madrasas. He believed that these crises prompted saner elements of the Muslim society to establish schools, colleges and universities where religious education was introduced along with the secular education (Maududi, 2009). The proportion of blending could be of three different proportions:

1. Smaller dose of Islamic education with a heavy dose of secular education.

2. Heaver dose of Islamic education with a smaller dose of secular education.

3. The blending can be of an equal proportion.

Maududi however, clearly states that none of the blending can serve the purpose of Islamization instead; it will only intensify the intellectual dilemma of students. For him any blending of this sort was not only unrealistic from an academic point of view but, it appears to him, also corrosive to the foundation of Islam (Maududi, 2009).

To him this experiment was destined to fail and he explains its failure in the following words:
Since religious and secular learning represent two diametrically opposed concepts of life, it is difficult for students to synthesize them into a unified pattern. Unable to reconcile the two divergent philosophies of life students are exposed to the dangers of religious skepticism which ultimately leads them to heresy. As long as students are exposed to secular education, the illusion of religious education is an exercise in futility (Maududi, 2009).

Maududi then after proposes his vision of education system by stating that Muslims need to did away both the systems and replace them with an entirely new system of education. His new system of education is based on Islamic $^{6}$ ideology whose objectives were believed to be in consonance with the Islamic culture and ideology. He cautions that it is suicidal for a nation if its education system does not promote the nations' culture and ideology (Maududi, 2012). Maududi's conception of Islam determines his socio-religious and educational thought. His vision of Islam is comprehensive and all compassing. He understands Islam as a way of life, complete in all respects. Religion can be name of certain rituals, moral codes, does and do nots but Deen is a comprehensive term used for that system of life where Allah's commandments run supreme in all shades of life, thus represents a complete code of life. ${ }^{7}$ It is his reading and interpretation of Islam that make it a political ideology and a guide to programmatic action. Therefore, he, while presenting Islam as a totality by constructing it as a holistic way of life, hence, adheres to kind of Islamism that idealizes Islam. The establishment of Islamic state was declared as the final destiny of his party (Maududi, 2014). It is to be noted that what Islamic ideology is for academicians, for Maududi it is Islam. Under his vision of Islam, he finds it obligatory to transform secular education into Islamic education by restructuring it in a manner that it falls in line with the principles of Islam. Maududi then clarifies his basic aim of educational reforms in the following words: The students and the teachers, in his new system of education, inspired by religious fervor and equipped with revolutionary strategies could launch their struggle to establish a state, a complete social system on Islamic principles, which would, according to him, ultimately lead the world (Maududi, 2013). He believed that the edifice of Muslim education should be constructed to meet both religious as well as secular demands. His system of education aimed to produce Muslim doctors, Muslim engineers, Muslim politicians etc. he was 
convinced that none of the then existing systems were committed to Islamic ideology nor were they in a position to produce men who could serve the needs of an Islamic movement (Maududi, 2009). His new education is motivated to produce upright men to carry the Islamization movement forward.

\section{INTEGRATION OF KNOWLEDGE: A NURSIAN PERSPECTIVE}

Said Nuri was dissatisfied with the education of his times. As mentioned, at the time the education system had two tiers, religious and secular. Nursi believed that this education system caused a chasm between religious scholars not familiar with the modern education and the modernists not familiar with the religious education. Hence, he proposed his own integrated model of education. He proposed a university called Medresetu'zZehra which would bring the two tiers together. Nursi writes in Munazarat,

In this university (Medresetu'z-Zehra, the sister of AlAzhar University of Cario) the language of Arabic is obligatory, the language of Kurdish is acceptable, and the language of Turkish is to be necessary (Gok, 2016).

Said Nursi's dissatisfaction with the Madrasa education became evident as he wondered from one Medrasa to another in search of the desired knowledge. His wondering reflected the dissatisfaction of Nursi; it also hinted towards reformation of Madrasa education. Markham writes that 'his travels around the medāris continued for about five years and left Nursi unsatisfied with his experience. He did not fit in the education system of the time and was disappointed with not finding the type of quality and attentive education he sought (Markham and Birinci, 2011). Dissatisfied with the entire system of education, Nursi approached the course through his own methodology. ${ }^{8}$ Said's aim, writes Vahide, in opting for his own method was to point out the need for reform in Madrasa education (Vahide, 2005). The condition of Turkish Madrasas is summarized by Vehide in the following words:

With their syllabi and curricula virtually unchanged since the fifteenth century, their buildings in advanced stage of decay, the student facilities nonexistent, and their independent source of income (the pious foundations) having been appropriated by the central government in 1840, the condition of the Madreses by the end of Abdulhamid's reign can only be described as lamentable (Vahide, 2005). The roots of this educational decline can be traced in Tanzimet period ${ }^{9}$ reforms. The reforms of Abdulhamid $^{10}$, according to Vahide, also played their part in the decline of the Medrese education (Vahide, 2005).

Makatib and madaris represented two different approaches to knowledge. The former represented a positivist approach to science while as the later represented classical Islamic education. There was not a single influential educational institution where religious and modern education was taught together, instead, makatib and madaris were taking a great pride in their separate curricula and were critical of each other (Markham and Birinci, 2011). Having received madresa education and having equipped himself with the modern scientific knowledge, ${ }^{11}$ Nursi now proceeded to formulate his ideal system of knowledge. He identified the main problems in the existing system and formulated his own solutions. He proposed to establish a University in Eastern Anatolia, a university where religious education will be taught along with modern sciences. He named this university as Medresetu'z-Zehra. Nursi stated that 'the religious sciences are the light of the conscience and the modern sciences ("the sciences of civilization") are the light of the reason; the truth becomes manifest through the combining of the two. The students' endeavor will take flight on these two wings. When they are separated it gives rise to bigotry in the one, and wiles and skepticism in the other' (Vahide, 2005; Markham and Birinci, 2011).

Nursi moved to Istanbul, the capital of Turkey in 1907, to present his proposal for the University to Sultan. He was also motivated to engage with broader spectrum of intellectuals, scholars and officials in Istanbul (Markham and Birinci, 2011). Vahide, however, believe that he moved to the capital for getting support for the Islamic university (Vahide, 2005; Markham and Birinci, 2011). His idea to move to the capital was motivated by his educational views and his aim to propose reforms. Nursi was greatly concerned with the growing gap between mekteb and medrese scholars and Students. He wanted to share his apprehension and warn against the dangers of such a split among the educated of the nation. Accordingly, he proposed integration of religious education with modern sciences. This blending, Nursi believed, could be could either a major in science with a minor in religion or the other way round (Markham and Birinci, 2011). Like Maududi, this blending did not trouble Nursi. 
Said was not only dissatisfied with the methodology and the curriculum of the Madrasa education but was also pained to see disunity among the three main streams of education-the religious schools, the modern schools and the sofi tekkes. He believed that this disunity among the three has been the biggest reason for Muslim backwardness (Balci, 2013). According to Vahide, the heart of Nursi's proposal lay in reconciling the three main branches of education system-the Medrasa, the Maktab and the Sofi Tekkes and the disciplines they represented (Vahide, 2005; Markham and Birinci, 2011). By order (unity), Nursi meant, not only the Divine Unity, ${ }^{12}$ or socio-political unity of the Ottoman Empire, but he also meant significant deficiencies in the internal structure of the Madrasas. He found that the Madrasa education was producing only 'one dimensional man'13, hence were fast becoming irrelevant. Nursi, like Maududi, criticized the Madrasas for being unable to provide and produce people suitable to the needs of the time.

He was in favour of democratization and diversification of the Madrasa education so that the rule of division of labour could be applied (Vahide, 2005; Markham and Birinci, 2011). He insisted to transform Madrasas on University lines whereby they will not only develop specialization but will also grow in cooperation and coordination. By progress, he meant scientific advancement in both methodology as well as the content. He viewed stagnation of Madrasas as the root cause of the misery and downfall of the Muslim world. He criticized the ages old syllabus taught in the Madrasas, which, he believed had no relevance. He criticized Madrasas for lacking dynamism and for want of producing the desired results (Canan, 19920). He also criticized Madrasa education for lack of professional training (Vahide, 2005; Markham and Birinci, 2011).

In the heart of Nursi's educational reforms, was the integration of secular and the sacred branches of education and the embodiment of this rapprochement was to be the Medresetu'z-Zehra. The thought of uniting religious education with the modern education developed during the course of fifteen years of Nursi's stay in Van, where he interacted with government officials who were trained in modern sciences and were raising different doubts about Islamic theology (Balci, 2013). He also realized that the traditional form of Islamic theology was incapable of answering these doubts and criticisms (Vahide, 2005; Markham and
Birinci, 2011). For Turkish modernists it was Islam and the Islamic culture that was regarded as the major cause for centuries of backwardness and the lack of development in science and technology, so, for them, there was only one solution: Islam had to be removed from social, public and political structures. Nursi, therefore, took the challenge to show that Islam and modernity, Islam and scientific progress are not incompatible, rather, go hand in hand (Turner, 2009). The conditions presented a golden chance for Nursi to develop his discourse and aim to reconstruct the society on the foundations of true belief in the Quran. So he came to the conclusion that religious courses should be taught in the modern schools and the modern sciences should be taught in the traditional schools. He believed that his method was fruitful in the way that it will save the maktab students from irreligiosity and the madrasa students from bigotry and ossified ideas (Balci, 2013). Unlike Maududi whose system of education is politically motivated, Nursi's method is purely faith oriented.

While presenting his proposal for establishing Medresetu'z-Zehra, he believed that the institution will not only serve as the basis for education but will also provide stability and development for the nation (Ibid). Education to Nursi was not only an enlightening force but also a source of political and economic stability. He looked on religious education as a uniting force, which makes people easy to govern. To him neglect of religious education leads to anarchism (Tatli A., 1992). Hakkan Gok (2016) believes that Nursi's idea 'would arguably have been the solution to the Kurdish problem that remains to this day' (Gok, 2016).

Upholding the Word of God: Nursi believed that three enemies: ignorance, poverty and conflict were responsible for the downfall of Muslims, especially the Ottoman Empire. He regarded ignorance as the chief of all evils and stressed to wage jihad against the three enemies with weapons of industry, learning and unity (Nursi, 2010) He firmly believed that the remedy of ignorance was to be found in the sciences and to him; it was only through scientific advancement only that the word of God can be held. He regarded material progress as a religious obligation for all Muslims. In his words, "all believers are charged with upholding the word of God, and at this time, its greatest cause is to progress materially (Turner, 2009). Nursi regarded the three (ignorance, poverty and conflict) the worst enemies of upholding the 
word of God (Nursi, 2010). Nursi did not see any incompatibility in Islam and pure science, instead, he believed that scientific discoveries uncover the working of the cosmos, hence is an excellent guide to understand the signs of Allah. For him, science is a genuine effort to reach for the truth and truth is the word of God, so inching towards the truth is simply marching towards Islam. So he predicted Islamic revivalism not only in the East but also in the West. But his revivalism is reasoned, self-motivated, based firmly on belief in the truth (Nursi, 2010; Balci, 2013). Nursi believed that Islam was the religion of present and the future because it relies on reason and reasoned proof; it does not teach abandonment of proof in favour of blind obedience, so in the age of science Islam stands authenticated (Nursi, 2010). In Muhkemat Nursi writes that 'Truth will grow and flourish' in present age of reason (aql). He believed that reason, truth and wisdom produce the steam of scientific truths and stated loudly that truth would prevail over force, proof over sophistry, reason over instinct and thought over emotions (Vahide, 2005; Markham and Birinci, 2011). Nursi concludes that the future belongs to Islam and only Islam alone (Vahide, 2010).

Maududi too, did not discourage the reading and teaching of modern sciences but he firmly believed that education cannot be only for the sake of attaining knowledge rather; it must serve a purpose. In his proposed system of education, the education has to promote Islamic culture and ideology and should prepare skilled people for an Islamic state. He did not question the scientific facts but vehemently criticizes the manner these facts and findings are presented, and the conclusions drawn from them. He criticizes the process of disseminating and digesting of these conclusions derived from the facts. For him conclusions derived can never be unbiased, as humans cannot be detached beings. Detachment of that kind is peculiar only to cameras; however, humans have gifted eyes as well as a mind, so when mind is applied in presenting and explaining these scientific truths, ideology is always taken care of (Maududi, 2015). Pure science and Wahi does not contradict, rather ideologically ridden sciences and the Wahi are definitely incompatible. He states that if sciences (social as well as natural) are taught without any reference to Allah, if the environment is encountered without any reference to the Creator, the world will become a godless world and the students will automatically turn to atheism (Maududi, 2013; Maududi, 2015). He, therefore, stressed on Islamization of sciences so as to do away with the atheistic orientations of these subjects. Nursi also states that modern education should be filtered so as to purify it from its negative impacts before it is accepted and taught. He entrusts this duty of unification to Islamic scholars (Nursi, 2010).

\section{CONCLUSION}

Maududi's vision of education is in real sense Islamization of knowledge according to his own prism of Islamism. His Islamization has to serve two important purposes: to indoctrinate the young ones according to his theory of Islamism so that they become active members for bringing a political revolution; second, once the Islamic state is established, his system of education aims to maintain it by producing men useful for effective working of the Islamic state. On the other hand, Said Nursi in not concerned about the nature of the state, neither does he tries to bring compatibility between the ideology of the state and the purpose of the education. He seems more concerned about faith of the individual rather than the nature of the state. $\mathrm{He}$ undertook to renew the belief the belief of Muslim individuals rather than re-establishing the political structure of the Islamic world. It is here that one sees a fundamental difference between Siad Nursi and his contemporaries including Maududi. Said Nursi did not favor any uprising or revolution in the name of Islam nether did he favored politicization of Islam. His policy of education shows that one can be faithful even in a secular state.

\section{REFERENCES}

Al Quran

Abu-Rabi, I. M. (2003). Islam at the Crossroads. New York: State University of New York.

Balci, R. (2013). Said Nursi 'Wonder of the Age'. Clifton: Tughra Books.

Gok, H. (2016). Rasal-i-Noor, Selected Readings from Bediuzzaman Said Nursi. Clifton: Tughra Books.

Hokru, C. T. (2009). Said Nursi, Oxford: Oxford University Press.

Mardin, S. (1989). Religion and Social Change in Modern Turkey. New York: State University Press.

Maududi, M. S. (2018). Tafheem-ul-Quran, Vol, II , New Delhi : Markazi Maktaba Islami Publishers

Maududi, M. S. (2018). Tafheem-ul-Quran, Vol, VI, New 
Delhi : Markazi Maktaba Islami Publishers

Maududi, M. S. (2013). Al Jihad Fil Islam. New Delhi : Markazi Maktaba Islami Publishers.

Maududi, M. S. (2015). Islami Nizam-e- Taleem. New Delhi: Markazi Maktaba Islami Publishers.

Maududi, M. S. (2014). Islami Nizam-e-Zindagi Aur Uske Bunyadi Tassaurat. New Delhi: Markazi Maktaba Islami Publishers.

Maududi, M. S. (2020). Islam's Political Order: The Model, Deviations and Muslim Response. Srinagar: Millat Publications.

Maududi, M. S. (2013). Jamaat-e- Islami Ke Untees Saal. Lahore: Islamic Publications Private Limited.

Maududi, M. S. (2015). Quran Ki Chaar Bunyadi Istilahen. New Delhi: Markazi Maktaba Islami Publishers.

Maududi, M. S. (2012). Tasrihaat. New Delhi: Markazi Maktaba Islami Publishers .

Maududi, S. A. (2013). Taleemat. New Delhi: Markazi Maktaba Islami Publishers.

Maududi, S. A. (2009). The Education. New Delhi: Markazi Maktaba Islami Publishers.

Nasr, S. V. (1994). The Venguard of the Islamic Revolution: The Jamaat-e-Islami of Pakistan,
Berkeley: . California: University of Californian Press.

Nursi, S. (2010). The Damascus Sermon. New Delhi: Barla Publications.

Nursi, S. (2015). The Flashes. New Delhi: Barla Publications.

Nursi, S. (2015). The Letters. New Delhi: Barla Publications.

Nursi, S. (2015). The Rays. New Delhi: Barla Publications.

Nursi, S. (2015). The Words. New Delhi: Barla Publications.

Pirim I. S. (2011). An Introduction to Said Nursi, Life, Thought and Writings, England: Ashgate.

Vahide, S. (2005). Islam in modern Turkey. New York: State University Press.

Sheikh Javaid Ayub (2020). Integrating Secular and the Sacred Branches of Knowledge: Bediuzzaman Said Nursi's Perspective. Katre International Human Studies Journal: Turkey, ISSN: 2146-8117 e-ISSN: 2148-6220, pp, 224-236.

Prof. Hamid Naseem Rafiabadi (2021), Educational Philosophy of Maulana Mawdudi (RA), Rising Kashmir, Srinagar: March 12, 2021.

${ }^{1} \mathrm{He}$ is referring to the Quranic Verse 'We did indeed offer the Trust to the heavens, and the earth, and the mountains; but they refused to undertake it being afraid thereof. But man assumed it; indeed, he is most unjust, most foolish'. Al Quran, Chapter 33, Verse, 72.

${ }^{2}$ For instance see the Twelfth Word in The Words, 2015: 143-149, The Third Ray in The Rays, 2015.

${ }^{3}$ Plato's system of education is essential for maintaining his ideal state.

${ }^{4}$ Some of the biographers have mentioned the year as 1877, for example see Ramazan Balci (2009), Bediuzzaman Said Nursi 'wonder of the Age'.

${ }^{5}$ Said Nursi moved to Van on invitation of Hasan Pasha, the Governor of Van, in 1895 or 1896 (Sukran vahide, 2005, Islam in Modern Turkey: 27). He stayed there for next fifteen years.

${ }^{6}$ As he understands it to be.

${ }^{7}$ For comprehensive understanding of the term Deen read Maulana Maudoodi's Quran ki Chaar Bunyadi Istilahen, New Delhi: Markazi Maktaba Islami Publishers, 2015: 93-101. See also Maulana Syed Abu Ala Maudoodi, Islami Nizam -eZindagi Aur Uske Buniyadi Tassaurat, New Delhi: Markazi Maktaba Islami Publishers, 2016: 91-117.

${ }^{8}$ Nursi while staying in the Madrasa of Sheikh Mohammad Celali in Bayezit developed his unique approach to the course. He completed the entire course then prevalent in madrasas in just three months. Vehide writes that such course, with the methodology it was taught then 'took the average student under normal conditions ten to fifteen years. The works studied under traditional method were 'heavily annotated with commentaries, commentaries on commentaries, and even commentaries on those commentaries. Nursi ignored all these commentaries and concentrated on only the most important sections in each work (Vahide, 2005:10).

${ }^{9}$ The Tamzimet is the name given to 37 years period from (1839-76) in which the Ottoman sultans introduced large scale reforms in government, administration and many areas of the Ottoman life along Western line. The motive was to restore the empires fast declining power (Vahide,2005: 34) 
${ }^{10}$ Abdulhamid built hundreds of schools, and in some schools, attempts were made to teach modern sciences with religious science but, according to Markham, 'due to a deep social cleavage, only a small minority benefited from these schools' (Markham, An Introduction to Said Nursi:10).

${ }^{11}$ Nursi's stay in Van, helped him to acquaint himself with modern sciences. His friendly relations with Tahir Pasha gave his access to Tahir Pasha's library, where he studied math, physics, astronomy, chemistry, biology and geology, and gained depth into history and philosophy. (Markham, 2011: 9; Vahide, 2005: 27)

12 Nursi has been elaborative in explaining Divine Unity in 'The Words'. See first to seven Words, Twenty-Second Word, thirty-Second and Thirty-Third Words in The Words, See also the Second chapter of The Seventh Ray in The Rays, 2015: 170.

${ }^{13}$ A Phrase used by Herbert Marcuse.

Publisher's note: EScience Press remains neutral with regard to jurisdictional claims in published maps and institutional affiliations.

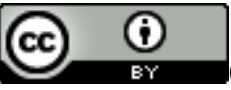

Open Access This article is licensed under a Creative Commons Attribution 4.0 International License, which permits use, sharing, adaptation, distribution and reproduction in any medium or format, as long as you give appropriate credit to the original author(s) and the source, provide a link to the Creative Commons license and indicate if changes were made. The images or other third-party material in this article are included in the article's Creative Commons license, unless indicated otherwise in a credit line to the material. If material is not included in the article's Creative Commons license and your intended use is not permitted by statutory regulation or exceeds the permitted use, you will need to obtain permission directly from the copyright holder. To view a copy of this license, visit http://creativecommons.org/licenses/by/4.0/.

(C) The Author(s) 2020. 